\title{
Comparisons of Energy Efficiency Management Techniques in Cloud Based Environment
}

\author{
Krishan Tuli , and Dr. Amanpreet Kaur \\ Research Scholar, Chandigarh University. \\ ${ }^{\text {b} A s s o c i a t e ~ P r o f e s s o r, ~ C h a n d i g a r h ~ U n i v e r s i t y . ~}$
}

Article History: Received: 11 January 2021; Accepted: 27 February 2021; Published online: 5 April 2021

\begin{abstract}
Cloud computing has been transforming large part of various IT services into virtualization which are made available as a utility services and scheduling plays a vital role here to get maximum utilization from various physical resources. Cloud Computing has been offering its virtual resources and services anywhere and anytime on pay-as-you-go basis. So, Cloud Computing becomes a backbone in the various fields of Industry and Academia for providing the storage backups, load balancing and most importantly providing the dynamic resource scheduling on a real-time basis. Therefore, energy consumption will be very high by the various clod data centers which lead to very high amount of operational cost and harm the environment as well. Hence, there is a requirement of Green Computing for the sustainability and ensuring the energy efficiency by energy efficient techniques. In present scenario, various energy efficient algorithms have been proposed by the researchers which reduce the energy efficiency of cloud environment. But all these algorithms have been evaluated using the same experimental environment which gives the related results and it becomes difficult for the researchers to choose the best algorithm among them. So to provide the better understanding on the various algorithms and helps researchers for choosing the best suitable algorithm, we have compared the various state of art energy efficient algorithm in more detailed way considering various prospective. Along with the comparison, we have also done studied the overview of investigated algorithm. Finally, we have the literature survey of various others related to different parameters and techniques. From the same literature survey, we have come to the conclusion of each author's statement.
\end{abstract}

Keywords: Cloud Computing, Energy efficient algorithms, Virtual Machine, Physical Machine, Quality of Service (QoS)

\section{Introduction}

Cloud Computing is having number of merits over the traditional computing systems. Cloud computing is very essential component of sophisticated computing technologies. Over the past centuries, computing ideas, computing, and architectures have evolved and strengthened [1]. Many elements are subordinate to the evolution and revolution of technology. Cloud Computing is a computing environment that moves fast as the next stage in developing and deploying the number of distributed applications [2]. To get the highest advantage from cloud computing, designers need to develop processes to optimize the use of paradigms for architecture and implementation. The entire cloud framework is divided into three subparts namely; Service customer, cloud specific infrastructure, supporting infrastructure as depicted by the blue, yellow and the orange colour respectively in Figure 1.

The evolving technology has recently awarded fresh computing models in which assets such as online apps, technology energy, transport, and network infrastructure can be distributed as internet facilities. The most cloud computation suppliers, common service computation system is inspirational characteristics for clients whose requirement for digital assets varies over the moment. In contemporary data hub and cloud computing applications, this consumption is a censorious layout parameter. The electricity and energy produced by software machinery and the linked heating unit are a significant component of these energy costs and high carbon emissions [3].

Cloud computing has been providing a computational and storage services to the users and made available on pay-as-you-go basis to all the users. In other words, we can say that this can be used on the basis of subscription i.e pay, as much you have used. There are various other services provided by cloud computing. They are also known as the service layers of cloud computing. These services are divided into three different types. They are Infrastructure as a Service (IaaS), Platform as a Service (PaaS) and Software as a Service (SaaS). Software as a Service is also known as Application as a Service Cloud model. All these services are available on Pay-as-you-go basis without restriction on the geographical areas [1] [2].

Datacenters, on the other hand is like a farmstead that has a vast collection of servers that provide numerous services to the users like storage, data management, networking, applications uses, different OS usage and backup and recovery [3] [4]. Much energy is used by the cooling systems at their infrastructure level just to cool down the datacenters that produces lots of heat and on the other hand lot of energy is consumed by the systems when they are in their idle state [4] [5]. 

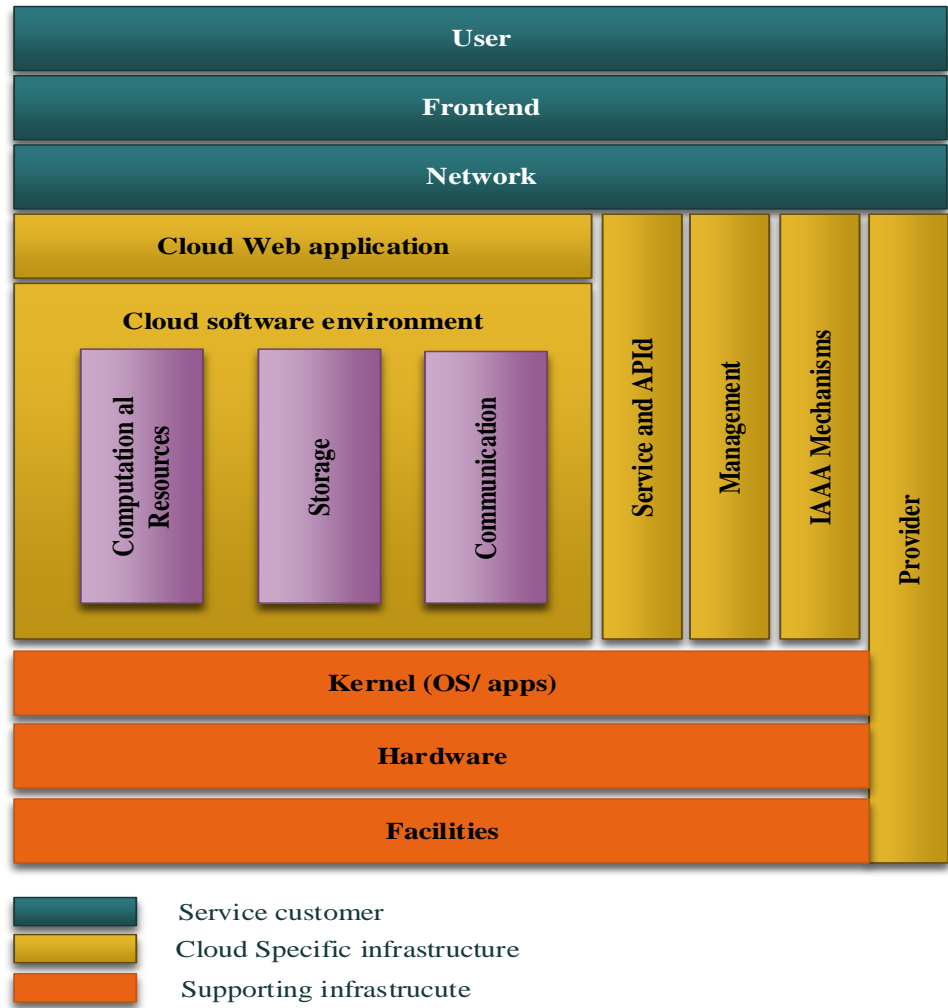

Figure 1. Cloud Architecture

Hence, both users as well as the service provider will get a huge financial loss. A typical datacenter can consume approximately 25,000 KWh per day. As per one of the report by Gartner in the year 2017 [6], there will be increase in electricity consumption of various data centers by 12.02 Billion $\mathrm{kWh}$ by year 2020 which is equivalent to around 50 coal based power plants. So as per present scenario, trustworthiness and energy efficiency are the major challenges in datacenters and if power management strategies are not applied on to datacenters now then this will goes on increasing continuously. So, to get rid of the problem of energy consumption and carbon that will be released daily, we need one energy efficient technique in cloud data centers [5] [6].

\section{Related work}

Virtualization in cloud computing is the most critical part in the cloud data centers to support and maximize the energy efficiency using virtual machines consolidation. Virtual Machines are the software implementation that runs on the operating system and other various applications [3]. On the other hand, VM consolidation is the process of reallocations of physical machines without even affecting the executions of user requests. VM consolidation is considered to be the best energy efficient solution for the reduction in the energy consumption of cloud datacenters [5]. The important point in VM consolidation is, to turn off or moved to low power mode to the machines which are at idle state for long time. The main aim of these algorithms is to optimize the placement of VM for the purpose of reduction in energy consumption with violating the service level agreement (SLA) [5] [7]. With the reason of huge network traffic, it becomes harder to conduct the experiment under such environment. So such experiments are also validated on various simulated environment. Such simulated toolkits can provide the large environment and produces best results. Among all the simulation toolkits, CloudSim is one of the best simulation toolkits that are most widely used now days. CloudSim can support cloud data centers which includes resource scheduling processes, Virtual Machines, Physical Machines and Load balancing. Considering all these features makes cloudsim attractive among the universities and researchers. Also there are other simulators working as the same way and have just the enhancement of cloudsim. They are CloudAnalyst and NetworkCloudsim [11] [12].

Cloud Computing has really improved the IT industry by introducing the concept of elastic scheduling and on demand allocation of various resources like storage, processing and networking but this system also leads to the consumption of lots of energy and hence release in lot of carbon particles which are very harmful for the human beings [8] [9]. Many famous researchers has advised and worked on various algorithms of energy efficiency and to improve the utilization of different datacenters for the purpose of VM selection, migration and placement [8] [9]. There are various scheduling parameters which are used by the various researchers for optimizing there resources [9] [10].

In [11], author has mentioned about the role of cloud computing. Cloud computing works as a power consumer and also works as an energy efficient method if we are comparing with the traditional systems of computing. This paper will also discuss about the relative study of different energy efficient ways or methods in cloud environment. The author has also classified the power based on various efficient methods for clusters and grids. The survey shown 
in this paper is different from other surveys because this paper will discuss about two aspects i.e system performance and power consumption. Also, author has classified different methods of energy efficiency technique.

\section{Classification of energy efficiecy technique}

In the coming section, author has explained about the various techniques of energy efficiency and different ways for improvement in that techniques and there limitations. Figure 2 show the taxonomy of energy efficiency technique and further explained all the techniques and gives a detailed description of each in tabular format.

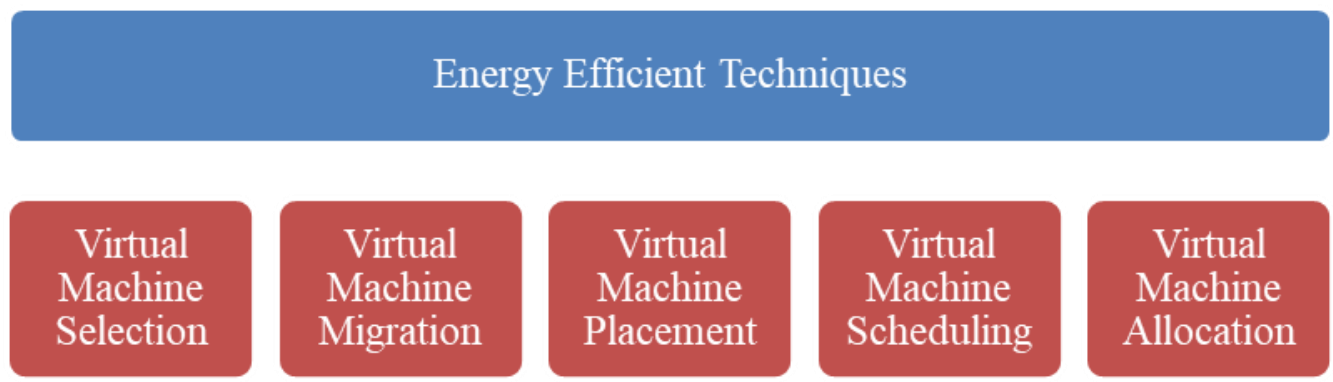

Figure 2. Classification of Energy Efficiency Technique

I. Virtual Machine Selection: The technique that is followed for the selection of VM is random virtual machine selection in which uniform distributed random variable is used for the selection of overloaded virtual machine for the purpose of migration [11]. Then the selection of VM is based on migration time. It should be minimum and in this method virtual machine which has minimum utilization should be migrated first.

II. Virtual Machine Migration: In [25], author has proposed a statistical method for that can estimate the power consumed by virtual machines with an error rate of around 3-6 percentage. In VM migration method, a threshold will be set for a server and if server exceeds that level of threshold only then the migration takes place for the reduction in energy consumption of the server. This migration process will be done without the violation on service level agreement and quality of service. The selection of VM migration is based on some of the policies. They are named as Device Type Manager, Field Device Tool and Distributed and Rake Technology.

III. Virtual Machine Placement: The development in the cloud data centres consumes lot of energy consumption. There are various methods and various techniques that have been proposed for the reduction in energy consumption but there is a problem with these techniques. They mainly focus on VM migration than resource utilization [20]. In [20], author has proposed a best technique for VM placement based on one of the approach called heuristic approach. In this approach, author has developed live migration model to enhance the resource utilization and to reduce the power consumption by the data centers. Live migration is one of the best techniques in VM Placement. Live migration is one of the techniques which allow the virtual machine to migrate from on one physical machine to another while VM's are running. It is very necessary for the process of virtualization with the following benefits. 1) Load balancing 2) Planned maintenance 3) Consolidation. The primary concern of service provider in the cloud focuses on two issues. Firstly, where to place the virtual machine at initial level and secondly where to transfer virtual machines when there is a requirement for movement. Any VM placement and migration algorithms are designed in such a way to detect the servers that are overloaded [19].

IV. Virtual Machine Scheduling: The algorithm for VM scheduling works on the heterogeneous machines and different workload scenarios for getting the best quality of service. One of the ideal ways to save energy consumption is to shot down the data centers when they are in idle state. In [29], author has proposed one algorithm named dynamic RR algorithm. Author has clearly shown the result of the paper that by applying DRR algorithm $43.7 \%$ of energy is saved and $60 \%$ of the resource utilization has been done. In [30], author has proposed a model which considers the running tasks in VM's for the estimation of power consumption by different VM's.

V. Virtual Machine Allocation: Cloud service providers allocate VM's to different users on their demand and further VM's are allocated to different physical Machine. There are various resource allocation methods that help resources for efficient allocation considering their utilization history. A cloud data center delivers various services to cloud applications that consume huge part of energy and hence produce huge amount of carbon. To get rid of this problem, [14] author proposed a model of energy-aware VM allocation scheme and improve QoS.

Table 1. Study of Energy Efficiency Algorithms

\begin{tabular}{|c|c|c|c|}
\hline $\begin{array}{c}\text { Energy Efficiency } \\
\text { Algorithm }\end{array}$ & Techniques Used & Inference Drawn & $\begin{array}{c}\text { Tools used to } \\
\text { Experimentation }\end{array}$ \\
\hline $\begin{array}{c}\text { Energy aware resource } \\
\text { allocation algorithm [14] }\end{array}$ & $\begin{array}{c}\text { VM- Selection \& } \\
\text { Placement }\end{array}$ & $\begin{array}{c}\text { Random variable are used for } \\
\text { selecting VM }\end{array}$ & CloudSim \\
\hline
\end{tabular}




\begin{tabular}{|c|c|c|c|}
\hline $\begin{array}{l}\text { Energy efficient resource } \\
\text { utilization algorithm [17] }\end{array}$ & VM Selection & Reduce carbon emission & CloudSim \\
\hline $\begin{array}{c}\text { Dynamic VM placement } \\
\text { algorithm [21] }\end{array}$ & VM Placement & $\begin{array}{l}\text { Reduction in power } \\
\text { consumption }\end{array}$ & $\begin{array}{c}\text { Simulator } \\
\text { (Self-designed) }\end{array}$ \\
\hline $\begin{array}{l}\text { Optimal deterministic } \\
\text { algorithm [16] }\end{array}$ & VM Selection & $\begin{array}{c}\text { Reduction in power } \\
\text { consumption without the } \\
\text { violation of SLA }\end{array}$ & CloudSim \\
\hline $\begin{array}{l}\text { Energy aware resource } \\
\text { allocation algorithm [23] }\end{array}$ & VM Placement & $\begin{array}{l}\text { SLA violation, power wastage } \\
\text { reduced and provided high } \\
\text { scalability }\end{array}$ & Power edge \\
\hline $\begin{array}{c}\text { Efficient allocation of virtual } \\
\text { machines [24] }\end{array}$ & VM Placement & Less SLA violation & CloudSim \\
\hline $\begin{array}{l}\text { Energy efficient dynamic } \\
\text { resource management [24] }\end{array}$ & VM Placement & $\begin{array}{l}\text { Minimize the power consumed } \\
\text { by data centers }\end{array}$ & CloudSim \\
\hline $\begin{array}{l}\text { Energy efficient VM } \\
\text { Placement [25] }\end{array}$ & VM Placement & $\begin{array}{l}\text { Reduces power consumed by } \\
\text { data centers and reduction in } \\
\text { rate of task rejection }\end{array}$ & CloudSim \\
\hline $\begin{array}{l}\text { Energy saving VM Migration } \\
\qquad[25]\end{array}$ & VM Migration & $\begin{array}{l}\text { QoS, power consumption is } \\
\text { efficient }\end{array}$ & Power edge \\
\hline $\begin{array}{l}\text { Exact allocation \& migration } \\
\text { algorithm [26] }\end{array}$ & VM Migration & $\begin{array}{l}\text { Minimum power consumption } \\
\text { \& Best QoS }\end{array}$ & $\begin{array}{l}\text { Java developed dedicated } \\
\text { simulator }\end{array}$ \\
\hline $\begin{array}{l}\text { Energy aware online } \\
\text { scheduling [27] }\end{array}$ & VM Scheduling & $\begin{array}{l}\text { Support heterogeneous } \\
\text { environment and maintain QoS }\end{array}$ & $\begin{array}{c}\text { Simulator } \\
\text { (Self-designed) }\end{array}$ \\
\hline $\begin{array}{l}\text { VM dynamic provision \& } \\
\text { Scheduling [28] }\end{array}$ & VM Scheduling & $\begin{array}{l}\text { Reduction in Energy } \\
\text { consumption }\end{array}$ & $\begin{array}{l}\text { Open source cloud } \\
\text { middleware - Eucalyptus }\end{array}$ \\
\hline $\begin{array}{l}\text { Energy based scheduling \& } \\
\text { accounting of VM [29] }\end{array}$ & VM Scheduling & $\begin{array}{l}\text { Reduction in Energy } \\
\text { consumption }\end{array}$ & Cloud Hypervisor - Xen \\
\hline $\begin{array}{c}\text { Dynamic energy aware } \\
\text { scheduling for parallel task } \\
\text { based application [32] }\end{array}$ & VM Scheduling & Minimize task execution time & Scheduler is implemented \\
\hline $\begin{array}{c}\text { Energy efficient VM } \\
\text { allocation technique using } \\
\text { interior search algorithm [33] }\end{array}$ & VM Allocation & $\begin{array}{l}\text { Efficient utilization of } \\
\text { resources }\end{array}$ & CloudSim \\
\hline $\begin{array}{l}\text { Novel resource allocation } \\
\text { algorithm for energy } \\
\text { efficiency [35] }\end{array}$ & VM Allocation & $\begin{array}{l}\text { Energy consumption is } \\
\text { efficient }\end{array}$ & CloudSim \\
\hline
\end{tabular}


Energy efficient VM

Management Scheme with

law of energy characteristics

[35]
Efficient resource allocation, energy efficiency
CloudSim

\section{Overview of investigated algorithm}

Figure below shows the architecture of virtual machines based on the consolidation of energy efficient algorithms in cloud data centers. This cloud architecture is generic in nature \& it has 4 different entities as shown below in the diagram.

1. Physical Machines: The infrastructure as a service cloud model will offer various physical machines to handle the user's request.

2. Virtual Machines: The users request are deployed and executed on virtual machines. The virtual machines management can be done according to the incoming requests by the users based on two phases. The first phase is called initial placement and second on is called VM migration. Virtual machines are placed according to the initial placement algorithm and that has been allocated to the physical machine. According to the user's request, placement can be improved via virtual machine consolidation algorithm which will further turn off the temporarily unused machines.

3. Energy efficient scheduler: Following components has been used to support the energy efficient scheduling and it acts as interface between the resources and user's.

a) VM Manager: VM manager manages and traces the resource usage for the making the better decisions on VM's and VM behaviours but without violating the SLA (Service Level Agreement).

b) SLA Monitor: It can check the performance constraint for managing or reducing the energy consumption.

c) Workload Analyser: it monitors various database activities and logs as needed in the system. Further the workload can be distributed to other virtual machines based on their characteristics.

4. Users: Users using the cloud will submit the request to the cloud and this request will be handled and processed by the cloud service providers.

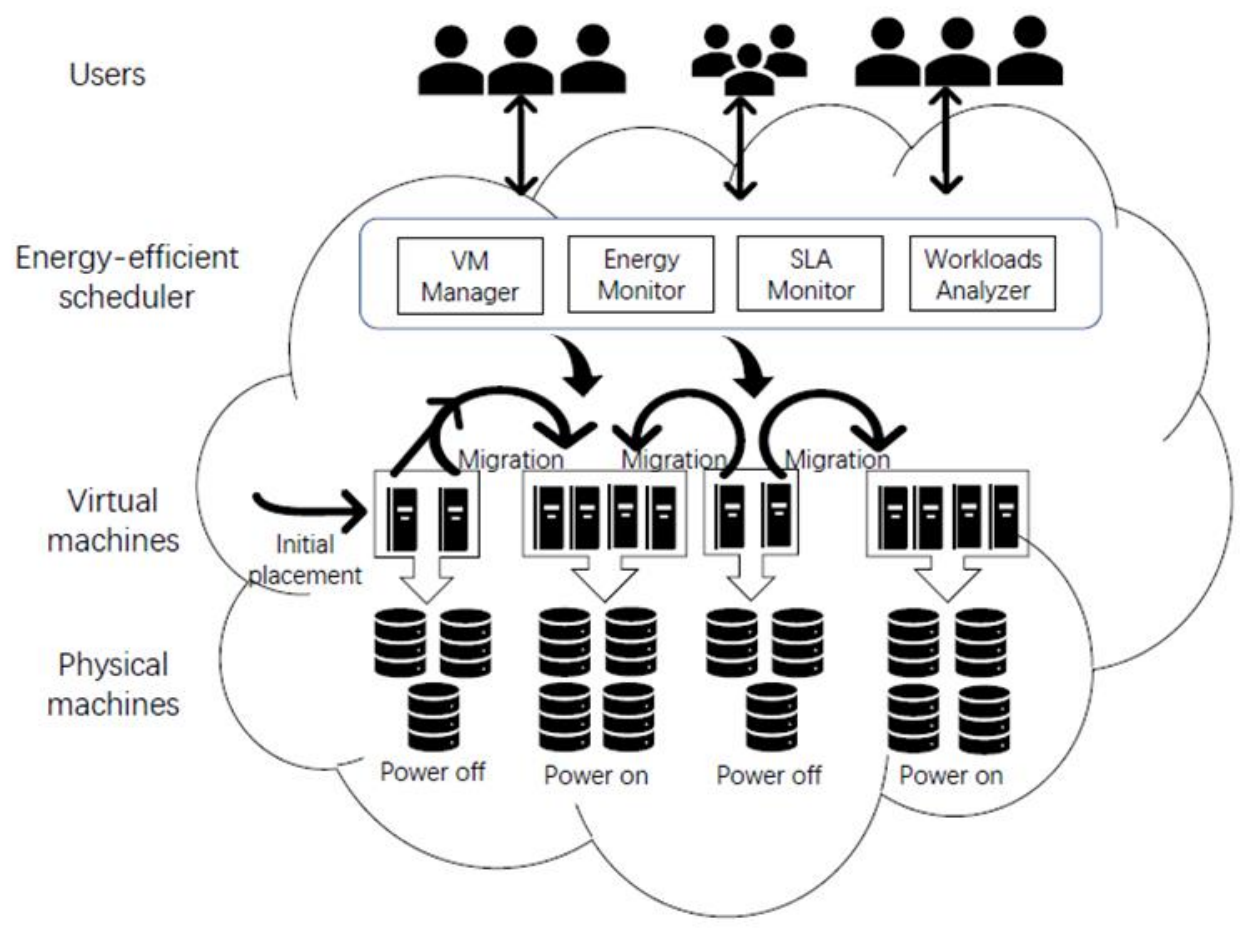

Figure 3. Energy efficient Scheduling based on Consolidation of VM's

On the basis of this overview, we have done the literature survey from different authors and from different papers.

Table 2. Literature Survey

\begin{tabular}{|l|l|l|l|l|l|}
\hline S. no & $\begin{array}{l}\text { Name of Paper } \\
\text { \& Author }\end{array}$ & Research Gaps & Techniques & Parameters & Findings \\
\hline 1 & $\begin{array}{l}\text { "Smart elastic } \\
\text { scheduling }\end{array}$ & $\begin{array}{l}\text { Duplication of } \\
\text { data transfer in } \\
\text { this work, like }\end{array}$ & $\begin{array}{l}\text { In this work mainly there } \\
\text { are two techniques has } \\
\text { been applied to distribute }\end{array}$ & $\begin{array}{l}\text { Total } \\
\text { consumed } \\
\text { power, amount }\end{array}$ & $\begin{array}{l}\text { The network traffic has } \\
\text { been reduced by } \\
\text { migrating the VMs that }\end{array}$ \\
\hline
\end{tabular}




\begin{tabular}{|c|c|c|c|c|c|}
\hline & $\begin{array}{l}\text { algorithm for } \\
\text { virtual machine } \\
\text { migration in } \\
\text { cloud } \\
\text { computing" } \\
\text { Nashaat et al. }\end{array}$ & 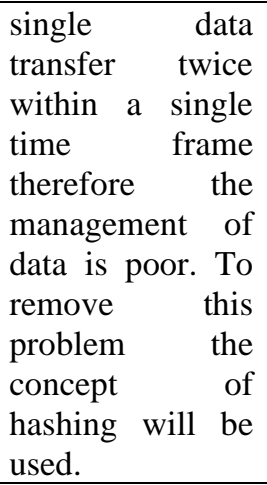 & $\begin{array}{l}\text { resources of physical } \\
\text { machine and balance the } \\
\text { load. These are: } \\
\text { (a) Smart elastic } \\
\text { scheduling algorithm } \\
\text { (SESA) and } \\
\text { (b) An adaptive worst fit } \\
\text { decreasing virtual } \\
\text { machine (AWFDVP) }\end{array}$ & $\begin{array}{l}\text { of migration } \\
\text { after that } \\
\text { performance } \\
\text { degradation. }\end{array}$ & $\begin{array}{l}\text { have used the same } \\
\text { memory space at the } \\
\text { same time. }\end{array}$ \\
\hline 2. & $\begin{array}{l}\text { "A Study of } \\
\text { Efficient } \\
\text { Energy } \\
\text { Management } \\
\text { Techniques } \\
\text { for Cloud } \\
\text { Computing } \\
\text { Environment" } \\
\text { Ali et al. }\end{array}$ & $\begin{array}{l}\text { Proposed } \\
\text { mechanism has } \\
\text { been applicable } \\
\text { on heterogeneous } \\
\text { a physical device } \\
\text { that requires } \\
\text { attention from } \\
\text { researcher sides. }\end{array}$ & $\begin{array}{ll}\text { Energy } & \text { Efficiency } \\
\text { Techniques. } & \end{array}$ & $\begin{array}{l}\text { Energy } \\
\text { Efficiency and } \\
\text { other QoS } \\
\text { parameters. }\end{array}$ & $\begin{array}{l}\text { Proposed work } \\
\text { demonstrated the study } \\
\text { about various mechanism } \\
\text { of energy management in } \\
\text { environment of cloud } \\
\text { computing. }\end{array}$ \\
\hline 3. & $\begin{array}{l}\text { "Enhancing } \\
\text { Reliability of } \\
\text { Cloud Services } \\
\text { Using } \\
\text { Mechanism of } \\
\text { Dynamic } \\
\text { Replication and } \\
\text { Migration of } \\
\text { Data" } \\
\text { Kaur et al. }\end{array}$ & $\begin{array}{l}\text { In the proposed } \\
\text { work cost, space } \\
\text { and time } \\
\text { complexity } \\
\text { associated with } \\
\text { migration is } \\
\text { reduced. }\end{array}$ & $\begin{array}{ll}\text { Various } & \text { Migration } \\
\text { Techniques. } & \end{array}$ & $\begin{array}{l}\text { Cost and } \\
\text { Execution } \\
\text { Time. }\end{array}$ & $\begin{array}{l}\text { Proposes an Enhanced } \\
\text { efficiency of cloud } \\
\text { services by utilizing the } \\
\text { scheme of dynamic } \\
\text { replication along with } \\
\text { data-migration. } \\
\text { The result shows } 25 \% \\
\text { improvement on the basis } \\
\text { of time as well as cost. }\end{array}$ \\
\hline 4. & $\begin{array}{l}\text { "Virtual } \\
\text { Machines } \\
\text { Placement } \\
\text { using Predicted } \\
\text { Utilization of } \\
\text { Physical } \\
\text { Machine in } \\
\text { Cloud } \\
\text { Datacenter" } \\
\text { Barthwal et al. }\end{array}$ & $\begin{array}{l}\text { In this work don't } \\
\text { improved the } \\
\text { VM selection and } \\
\text { PM overloading } \\
\text { detection to } \\
\text { develop better } \\
\text { solutions for } \\
\text { dynamic VM } \\
\text { Consolidations. }\end{array}$ & $\begin{array}{l}\text { Dynamic Consolidation } \\
\text { of Virtual Machine is the } \\
\text { technique. }\end{array}$ & $\begin{array}{l}\text { Energy (Kwh), } \\
\text { Migration } \\
\text { count, SLA } \\
\text { Violation }(\%) .\end{array}$ & $\begin{array}{l}\text { In this author, proposed a } \\
\text { placement of VMs on the } \\
\text { basis of predicted } \\
\text { consumption of physical } \\
\text { machine inside cloud } \\
\text { data centre. } \\
\text { This presented work } \\
\text { mainly focuses on the } \\
\text { consumption as well as in } \\
\text { the improvement of } \\
\text { service-level agreement. }\end{array}$ \\
\hline 5. & $\begin{array}{l}\text { "Energy Aware } \\
\text { Computing } \\
\text { Resource } \\
\text { Allocation } \\
\text { Using PSO in } \\
\text { Cloud" } \\
\text { Chaudhari } \\
\text { et al. }\end{array}$ & $\begin{array}{l}\text { Does not use the } \\
\text { active-source } \\
\text { cloud } \\
\text { environment in } \\
\text { the proposed } \\
\text { work to evaluate } \\
\text { the proposed } \\
\text { technique for } \\
\text { cloud hosts. }\end{array}$ & $\begin{array}{l}\text { Techniques to optimized } \\
\text { as well as management } \\
\text { of energy }\end{array}$ & $\begin{array}{l}\text { Energy } \\
\text { parameter. }\end{array}$ & $\begin{array}{l}\text { Authors demonstrate the } \\
\text { various techniques of } \\
\text { energy management. } \\
\text { In this Particle Swarm } \\
\text { Optimization, the result } \\
\text { for both allocations as } \\
\text { well as in migration of } \\
\text { VM that becomes better } \\
\text { to build efficient energy } \\
\text { hosts. }\end{array}$ \\
\hline 6. & $\begin{array}{l}\text { "LACE: A } \\
\text { Locust-Inspired } \\
\text { Scheduling } \\
\text { Algorithm }\end{array}$ & $\begin{array}{l}\text { The proposed } \\
\text { research does not } \\
\text { assess the } \\
\text { efficiency of }\end{array}$ & $\begin{array}{l}\text { DVFS consolidation is } \\
\text { observed integrated with } \\
\text { power management to } \\
\text { prevent more power }\end{array}$ & $\begin{array}{l}\text { Energy } \\
\text { Consumption, } \\
\text { Response Time }\end{array}$ & $\begin{array}{l}\text { Proposed a distributed } \\
\text { scheduling algorithm } \\
\text { inspired by Locust to can } \\
\text { the use of cloud }\end{array}$ \\
\hline
\end{tabular}




\begin{tabular}{|c|c|c|c|c|c|}
\hline & $\begin{array}{l}\text { to Reduce } \\
\text { Energy } \\
\text { Consumption in } \\
\text { Cloud } \\
\text { Datacenters" } \\
\text { Kurdi et al. }\end{array}$ & $\begin{array}{l}\text { LACE by } \\
\text { evaluating data } \\
\text { center } \\
\text { component of } \\
\text { encrypted traffic. }\end{array}$ & $\begin{array}{l}\text { while the execution of } \\
\text { the VMs. }\end{array}$ & & $\begin{array}{l}\text { computing resources } \\
\text { (LACE). } \\
\text { The outcome of this work } \\
\text { depicted that the LACE } \\
\text { increased the utilization } \\
\text { of resource rate up to } \\
\text { higher degree as compare } \\
\text { to two different } \\
\text { benchmark through } \\
\text { minimizing the amount } \\
\text { of active servers. }\end{array}$ \\
\hline 7. & $\begin{array}{l}\text { "Resource- } \\
\text { utilization- } \\
\text { aware energy } \\
\text { efficient server } \\
\text { consolidation } \\
\text { algorithm for } \\
\text { green } \\
\text { computing in } \\
\text { IIOT" } \\
\text { Han et al. }\end{array}$ & $\begin{array}{l}\text { Proposed works } \\
\text { don't focus on } \\
\text { the periodicity of } \\
\text { application. }\end{array}$ & $\begin{array}{l}\text { The server consolidation } \\
\text { algorithm named as } \\
\text { Resource utilization- } \\
\text { aware energy efficient } \\
\text { (RUAEE). }\end{array}$ & $\begin{array}{l}\text { Energy } \\
\text { Consumption } \\
(\mathrm{KWh}) \text {, The } \\
\text { number of VM } \\
\text { migrations, } \\
\text { SLAV, ESV. }\end{array}$ & $\begin{array}{l}\text { Proposed an energy- } \\
\text { efficient resource- } \\
\text { utilization-aware } \\
\text { database consolidation } \\
\text { algorithm (RUAEE) this } \\
\text { scheme is helpful in } \\
\text { utilization of resource } \\
\text { when minimizing the } \\
\text { amount of live } \\
\text { migrations of system. }\end{array}$ \\
\hline 8. & $\begin{array}{l}\text { "A Hybrid } \\
\text { Approach for } \\
\text { Task } \\
\text { Scheduling } \\
\text { Using } \\
\text { the Cuckoo and } \\
\text { Harmony } \\
\text { Search in Cloud } \\
\text { Computing } \\
\text { Environment" } \\
\text { Pradeep et al. }\end{array}$ & $\begin{array}{l}\text { Limitations are } \\
\text { maximum cost, } \\
\text { Time, } \\
\text { Complexity. }\end{array}$ & $\begin{array}{l}\text { A new combination of } \\
\text { Cuckoo Search (CS) } \\
\text { along with Harmony } \\
\text { Search (HS) is } \\
\text { integrated. }\end{array}$ & $\begin{array}{l}\text { Energy } \\
\text { Consumption, } \\
\text { Cost. }\end{array}$ & $\begin{array}{l}\text { This suggested a multi- } \\
\text { objective task scheduling } \\
\text { system based on the } \\
\text { hybrid approach of the } \\
\text { Cuckoo Harmony Search } \\
\text { Algorithm. (CHSA). The } \\
\text { result makes it clear that } \\
\text { the presented approach is } \\
\text { much enhanced as } \\
\text { contrast to other } \\
\text { technique. }\end{array}$ \\
\hline
\end{tabular}

\section{Conclusion}

Increased power consumption is the biggest problem now days. As the applications are increasing, it give rise to the problem of complicated data as well that require the need of new data centers which will further increase more need of energy. The above study and research of energy efficiency techniques, we can elaborate that to reduce the consumption in data centers can be done using VM-Scheduling and migration methods. Manu of the researchers has proposed an algorithm of multi-objective, which covers service level agreement, Quality of service and various resource utilization with great consumption in data centers. Very less work has been done on the heterogeneous physical machines which need a lot of attention.

\section{References}

1. Abdel-Kader, R. F., El-Sherif, S. H., \& Rizk, R. Y. (2020). "Efficient two-stage cryptography scheme for secure distributed data storage in cloud computing". International Journal of Electrical \& Computer Engineering (2088-8708), 10.

2. Aishwarya, R., \& Malliga, S. (2014). "Intrusion detection system-An efficient way to thwart against Dos/DDos attack in the cloud environment". In Recent Trends in Information Technology (ICRTIT), 2014 International Conference on IEEE, pp. 1-6.

3. Ala'Anzy, M., \& Othman, M. (2019). "Load Balancing and Server Consolidation in Cloud Computing Environments: A Meta-Study”. IEEE Access, 7, 141868-141887.

4. Ali, S. A., Affan, M., \& Alam, M. (2019). "A Study of Efficient Energy Management Techniques for Cloud Computing Environment," In 2019 9th International Conference on Cloud Computing, Data Science \& Engineering (Confluence) January 2019, pp. 13-18.

5. Alqahtani, S. M., Al Balushi, M., \& John, R. (2014). "An intelligent intrusion detection system for cloud computing". In Computational Science and Computational Intelligence (CSCI), IEEE, 2014 International Conference on Vol. 2, pp. 135-141. 
6. Barthwal, V., Rauthan, M., \& Verma, R. (2019) "Virtual Machines Placement Using Predicted Utilization of Physical Machine in Cloud Datacenter", International Conference on Advances in Engineering Science Management \& Technology (ICAESMT) Uttaranchal University, Dehradun, India, pp.1-6.

7. Basu, S., Karuppiah, M., Selvakumar, K., Li, K. C., Islam, S. H., Hassan, M. M., \& Bhuiyan, M. Z. A. (2018). "An intelligent/cognitive model of task scheduling for IoT applications in cloud computing environment". Future Generation Computer Systems, 88, 254-261.

8. Bhattacherjee, S., Das, R., Khatua, S., \& Roy, S. (2019) "Energy-efficient migration techniques for cloud environment: a step toward green computing", The Journal of Supercomputing, pp.1-29.

9. Chaudhrani, V., Acharya, P., \& Chudasama, V. (2018) "Energy Aware Computing Resource Allocation Using PSO in Cloud", In Information and Communication Technology for Intelligent Systems, Springer, Singapore, pp. 511-519.

10. Dashti, S. E., \& Rahmani, A. M. (2016), “Dynamic VMs placement for energy efficiency by PSO in cloud computing" Journal of Experimental \& Theoretical Artificial Intelligence, 28(1-2), 97-112.

11. Gai, K., Qiu, M., \& Zhao, H. (2016). "Cost-aware multimedia data allocation for heterogeneous memory using genetic algorithm in cloud computing”. IEEE transactions on cloud computing.

12. Han, G., Que, W., Jia, G., \& Zhang, W. (2018) "Resource-utilization-aware energy efficient server consolidation algorithm for green computing in IIOT", Journal of Network and Computer Applications, Vol. 103, pp. 205-214.

13. Jana, B., Chakraborty, M., \& Mandal, T. (2019) "A task scheduling technique based on particle swarm optimization algorithm in cloud environment", In Soft Computing: Theories and Applications Springer, Singapore, pp. 525-536.

14. Jensen, M., Schwenk, J., Gruschka, N., \& Iacono, L. L. (2009). “On technical security issues in cloud computing”. In Cloud Computing, 2009. CLOUD'09. IEEE International Conference on pp. 109-116.

15. John, J., \& Norman, J. (2019). "Significant Vulnerabilities and Their Prevention Methods in Cloud Computing”, Springer, Singapore, pp. 11-26.

16. Kansal, N. J., \& Chana, I. (2016), "Energy-aware virtual machine migration for cloud computing-a firefly optimization approach,”Journal of Grid Computing, pp. 327-345.

17. Kaur, S., \& Kaur, K. (2019) "Enhancing Reliability of Cloud Services Using Mechanism of Dynamic Replication and Migration of Data," International Journal of Applied Engineering Research, Vol.14, No.8,pp. 1976-1983.

18. Krishna does, P., \& Jacob, P, (2018) "OCSA: Task scheduling algorithm in the cloud computing environment," International Journal of Intelligent Engineering \& Systems, Vol.11, No.3, pp. 271-279.

19. Kumar, G. G., \& Vivekanandan, P. (2019). Energy efficient scheduling for cloud data centers using heuristic based migration. Cluster Computing, 22(6), 14073-14080.

20. Kurdi, H. A., Alismail, S. M., \& Hassan, M. M. (2018) "LACE: A Locust-Inspired Scheduling Algorithm to Reduce Energy Consumption in Cloud Datacenters", IEEE Access, Vol. 6, pp.35435-35448.

21. Latiff, M. S. A., Madni, S. H. H., \& Abdullahi, M. (2018) "Fault tolerance aware scheduling technique for cloud computing environment using dynamic clustering algorithm," Neural Computing and Applications, Vol.29, No.1, pp.279-293.

22. LD, D. B., \& Krishna, P. V. (2013) "Honey bee behavior inspired load balancing of tasks in cloud computing environments", Applied Soft Computing, Vol.13, No.5, pp. 2292-2303.

23. Lin, C. H., Tien, C. W., \& Pao, H. K. (2012). "Efficient and effective NIDS for cloud virtualization environment". In Cloud Computing Technology and Science (CloudCom), 2012 IEEE 4th International Conference on pp. 249-254.

24. Modi, C., Patel, D., Borisaniya, B., Patel, A., \& Rajarajan, M. (2012). “A survey on security issues and solutions at different layers of Cloud computing". The journal of supercomputing, pp. 561-592.

25. Moges, F. F., \& Abebe, S. L. (2019) "Energy-aware VM placement algorithms for the OpenStack Neat consolidation framework", Journal of Cloud Computing, Vol.8, No.1, pp.2-12.

26. Mohamad, Z., Mahmoud, A. A., Nik, W. N. S. W., Mohamed, M. A., \& Deris, M. M. (2018) "A Genetic Algorithm for Optimal Job Scheduling and Load Balancing in Cloud Computing”, International Journal of Engineering \& Technology, Vol. 7, No. 3, pp. 290-294.

27. Mohana, S. J., Saroja, M., \& Venkatachalam, M. (2014). "Comparative analysis of swarm intelligence optimization techniques for cloud scheduling”. International Journal of Innovative Science, Engineering \& Technology, 1(10), 15-19.

28. Mustafa, S., Nazir, B., Hayat, A., \& Madani, S. A. (2015). "Resource management in cloud computing: Taxonomy, prospects, and challenges". Computers \& Electrical Engineering, 47, 186-203.

29. Narayani, R., \& Banu, W. A. (2019). "Fairness-based heuristic workflow scheduling and placement in cloud computing”. International Journal of Vehicle Information and Communication Systems, 4(4), 355374.

30. Nashaat, H., Ashry, N., \& Rizk, R. (2019). Smart elastic scheduling algorithm for virtual machine migration in cloud computing. The Journal of Supercomputing, 75(7), 3842-3865. 
31. Pillai, Parvathy S., and Shrisha Rao. (2014), "Resource allocation in cloud computing using the uncertainty principle of game theory." IEEE Systems Journal 10, no. 2 (2014): 637-648.

32. Pradeep, K., \& Jacob, T. P. (2018) "A hybrid approaches for task scheduling using the cuckoo and harmony search in cloud computing environment," Wireless Personal Communications, Vol.101, No.4, pp.22872311.

33. Ragmani, A., El Omri, A., Abghour, N., Moussaid, K., \& Rida, M. (2018) “A performed load balancing algorithm for public Cloud computing using ant colony optimization”, Recent Patents on Computer Science, Vol.11, No. 3, pp.179-195.

34. Ruan, X., Chen, H., Tian, Y., \& Yin, S. (2019), "Virtual machine allocation and migration based on performance-to-power ratio in energy-efficient clouds,'Future Generation Computer Systems, 100, 380394.

35. Samrin, R., \&Vasumathi, D. (2017). "Review on Anomaly Based Network Intrusion Detection System". In 2017 International Conference on Electrical, Electronics, Communication, Computer, and Optimization Techniques (ICEECCOT) IEEE. pp. 141-147.

36. Shen, Z., \& Tong, Q. (2010). "The security of cloud computing system enabled by trusted computing technology”. In Signal Processing Systems (ICSPS), IEEE 2010 2nd International Conference on (Vol. 2, pp. 2-11).

37. Tang, M., Dai, X., Liu, J., \& Chen, J. (2017). “Towards a Trust Evaluation Middleware for Cloud Service Selection”. Future Generation Computer Systems, 74, pp. 302-312.

38. Tarahomi, M., \& Izadi, M. (2019) "New approach for reducing energy consumption and load balancing in data centers of cloud computing”. Journal of Intelligent \& Fuzzy Systems, (Preprint), pp. 1-13.

39. V.Krishna Reddy(2011). "Security Architecture of Cloud Computing", International Journal of Engineering Science and Technology (IJEST), pp. 7149-7155.

40. Wang, T., Li, Y., Fang, W., Xu, W., Liang, J., Chen, Y., \& Liu, X. (2018). “A Comprehensive, Trustworthy data collection approach in the sensor-cloud system". IEEE Transactions on Big Data. pp. 5-8

41. Zhang, X., Wuwong, N., Li, H., \& Zhang, X. (2010). "Information security risk management framework for the cloud computing environments". In Computer and Information Technology (CIT), 2010 IEEE 10th International Conference on pp. 1328-1334.

42. Zhu, L., Wu, Y., Gai, K., \&Choo, K. K. R. (2019). “Controllable and trustworthy blockchain-based cloud data management". Future Generation Computer Systems, (pp. 91, 527-535).

43. Zhu, W., Zhuang, Y., \& Zhang, L. (2017). “A Three-Dimensional Virtual Resource Scheduling Method For Energy Saving in Cloud Computing”. Future Generation Computer Systems, 69, pp. 66-74. 